\title{
Zooarchaeological and Stable Isotopic Assessments on Pinniped-Human Relations in the Beagle Channel (Tierra del Fuego, Southern South America)
}

\author{
A. F. ZANGRANDO, ${ }^{a, c_{*}}$ H. PANARELLO ${ }^{b}$ AND E. L. PIANA ${ }^{a}$ \\ a CADIC-CONICET, Ushuaia, Tierra del Fuego, Argentina \\ b INGEIS-CONICET-UBA, Buenos Aires, Argentina \\ ${ }^{c}$ Museum of Natural History and Archaeology (Vitenskapsmuseet), Norwegian University of Science and \\ Technology, Trondheim, Norway
}

\begin{abstract}
Recent zooarchaeological investigations in the Beagle Channel region have shown long-term variations characterised by a high inter-taxonomic dominance of pinnipeds during the first moments of the archaeological sequence (ca $6400 \mathrm{BP}$ ) at the Túnel Locality and a decrease in the relative importance of this resource and a diversification of subsistence in that place since 5500 BP. Two possible explanations for these variations are evaluated: (i) variations in foraging habits of pinnipeds that would lead to changes in the degree of predictability or access to the resource and (ii) a reduction in resource availability because of increased human predation pressure. To analyse these arguments, this paper presents and discusses the results of an analysis of stable isotopes $\left(\delta^{13} \mathrm{C}\right.$ and $\left.\delta^{15} \mathrm{~N}\right)$ from collagen samples of South American fur seals (Arctocephalus australis) and representations of age and size of pinnipeds in the archaeological record of Túnel. Stable isotope analyses suggest that there were variations in the foraging behaviour of southern fur seals at the same time that zooarchaeological analyses record decreases of the ages and sizes of the hunted prey. On the basis of these results, an increase of hunter-gatherer predation pressure on pinnipeds to the Middle-Late Holocene in southern South America is suggested. Copyright (c) 2013 John Wiley \& Sons, Ltd.
\end{abstract}

Key words: carbon and nitrogen stable isotopes; human predation pressure; marine hunter-gatherers; Middle-Late Holocene; pinnipeds; Tierra del Fuego; zooarchaeology

\section{Introduction}

Pinnipeds were an essential subsistence resource for maritime hunter-gatherers which inhabited the Fuegian Archipelago between 6400 BP and the 19th century. These resources not only were a main part of the diet of these human groups (Schiavini, 1990, 1993; Legoupil, 1993; Orquera \& Piana, 1999a, 2009; Orquera, 2002; San Román, 2008; Zangrando, 2009a) but were also used as a source of raw materials (Hyades

\footnotetext{
* Correspondence to: Atilio Francisco Zangrando, CADIC-CONICET/ Norwegian University of Science and Technology, Museum of Natural History and Archaeology (Vitenskapsmuseet), Bernardo Houssay 200 (V9410CAB) Ushuaia, Tierra del Fuego, Argentina.

e-mail: panchozan@yahoo.com.ar, afzangrando@cadic-conicet.gob.ar
}

\& Deniker, 1891: 347; Orquera \& Piana, 1986, 1999a, 1999b: 338-343). Ethnographic information indicates that the capture of pinnipeds could be developed with the use of harpoons from canoes and from the coast, in this last case trying to retain the prey with a leash, or hitting the skull with a stick on land (Fitz-Roy, 1839; Hyades \& Deniker, 1891; Gusinde, 1986). The use of watercrafts and harpoons is evidenced in the archaeological record of the Fuegian Archipelago since 6400 radiocarbon years BP (Orquera \& Piana, 1999a). Two species of pinnipeds are present in the Fuegian Archipelago: the South American fur seals (Arctocepbalus australis) and the Southern sea lions (Otaria flavescens). However, zooarchaeological assemblages of the Beagle Channel are widely dominated by the former 
(Schiavini, 1990, 1993; Orquera \& Piana, 1999a). Therefore, this paper develops an isotopic and zooarchaeological study based solely on South American fur seal remains, discussing particularly the relationship between humans and this species.

A. australis has a wide distribution in this region and can be found throughout the year as individuals moving in the sea or in permanent or temporary settlements on coasts and small islands. Nevertheless, the majority of colonies for mating and pupping (rookeries) are located on outer coasts and islands of the archipelago, away from the inner channels (Sielfeld et al., 1978; Schiavini, 1990, 1993; Falabella et al., 2009). The age of sexual maturity is about 3 years old for female seals and 7 or 8 years old for male seals. Breeding occurs between November and December. Adult male seals defend territories throughout the breeding season, leaving the male seals which do not succeed in forming harems in the water around the breeding colonies. During the breeding season, the male seals of the harem does not feed, consuming fat reserves accumulated in prereproductive pelagic life. Reproductive groups disperse into January, and the female seals feed their pups during a period of 6 months to a year. Outside the breeding season, adult and young male seals spend more time in the water than on land, making long dispersions, but adult female seals must return continually to the breeding colonies to nurse their pups. In the breeding season, the female seals feed in areas near breeding colonies and the duration of foraging trips increases with time since the birth of the pups. Weaned pups remain feeding near the rockeries, but after a month, they move further (Schiavini, 1990, 1993).

The behaviour patterns of $A$. australis provide a useful framework for discussion of the archaeological evi-


of the actual range of behaviours and ecological roles that these resources could have offered for human populations in the past. The historical distribution of $A$. australis colonies in Patagonia and Tierra del Fuego is poorly known (Carrara, 1952; Sielfeld et al., 1978; Sielfeld, 1983). It has been suggested that the spatial structure of South American fur seal's colonies recorded in the present-characterised by a heterogeneous distribution oriented towards peripheral sectors of the Fuegian Archipelago-could be the result of a process in which the intervention of hunter-gatherers might have played a significant role (Vidal \& Winograd, 1986). Also, we do not know whether the overkill generated by sealers in the 18 th and 19th centuries, leading to the near extinction of this species in the South Atlantic (Bonner, 1981; Orquera, 2002), would have transformed its original distribution in the environment and caused the seal colonies' current distribution, which in fact is not a static one (Grandi et al., 2008). Against this background, the study of zooarchaeological assemblages provides a convenient route to expand our knowledge about the human-pinniped relations at long-time scales (Rick et al., 2011).

Determinations by sex, age and seasonality of death of A. australis remains from the second component of the Túnel I site (6400-4300 BP, north coast of the Beagle Channel) showed that most of the captures of the animals did not occur in rookeries. Hunting focused on male seals ( $83 \%$ of the remains of $A$. australis) and was concentrated between autumn and spring (Schiavini, 1990, 1993). The ecological parameters previously indicated and this zooarchaeological information led to think that human predation in the Beagle Channel waters on these marine mammals produced an input of energy to human subsistence originated in offshore waters and enabled by the movements of pinnipeds on long distances. This dynamic would have allowed pinnipeds to be the main resource to human subsistence throughout the occupational sequence without producing an impact on the population structure or their abundance in the environment (Orquera \& Piana, 1999a).

However, recent studies have shown long-term variations in the composition of zooarchaeological assemblages from the Beagle Channel region. Early assemblages (ca. 6400-5500 BP) are characterised by high frequencies of pinnipeds and limited representation of other vertebrates (e.g. guanacos, birds and fish), while a decrease in the relative importance of pinnipeds and a diversification in subsistence patterns have occurred from the 5500-5000 BP, increasing the importance of other resources in zooarchaeological assemblages (Zangrando, 2009a, 2009b; Zangrando et al., 2010; Tivoli \& Zangrando, 2011). In this sense, the proposal of Vidal \& Winograd (1986) can still be considered in the sense that human predatory action could have had an impact on pinniped behaviour, such as circulation scopes or foraging areas. This raises the following question: if there was a constant input of pinnipeds from offshore waters, inaccessible to the hunter-gatherers of the Beagle Channel, why does the representation of pinnipeds decrease over time? From our point of view, the answers to this question may lie in two hypothetical processes: (i) variations in foraging habits of pinnipeds that would lead to changes in the degree of predictability or access to the resource and (ii) a reduction in resource availability because of an increase of human predation pressure. The hunting patterns identified by Schiavini $(1990,1993)$ from the initial moments of the sequence do not permit a 
definitive analysis of possible spatial restructuring of the breeding colonies of A.australis, conjecturally located in the Beagle Channel towards the outer islands. Nevertheless, Legoupil \& Fontugne (1997) noted that there is a wide distribution of huntergatherer occupations in the Fuegian Archipelago and they proposed, on the basis of the spatial and temporal patterns of settlements, that the external islands became more important for human subsistence during the Late Holocene. Therefore, other questions remain open: what could be the effect of the later settlements of hunter-gatherers on the outer islands? Is there a relation between these settlements with the changes observed in faunal use from 5000 BP henceforth? What effect might have had the human pressure on breeding colonies located in offshore islands (e.g. Staten Island or Cape Horn), from where the pinnipeds could also enter the waters of the Beagle Channel and surroundings?

Resource depression or decline in encounter rates of pinnipeds may be caused both by changes in prey behaviour as in the behaviour of human predators (e.g. increase in harvest intensity because of population expansion and variations in technology) (Lyman, 2003; Betts et al., 2011). In this paper, we assess the relationship between pinnipeds and hunter-gatherers in southern South America on the basis of stable isotope and zooarchaeological analyses. First, we explore changes in A. australis foraging habitats that would lead to variations in their availability at different times of the archaeological sequence of the Beagle Channel. The foraging behaviours of pinnipeds between different marine zones can be monitored through changes in carbon and nitrogen stable isotopes (Burton \& Koch, 1999; Burton et al., 2001; Gifford-Gonzalez et al., 2005; Newsome et al., 2010). Recently, Riccialdelli et al. (2010) have noticed differences in $\delta^{13} \mathrm{C}$ and $\delta^{15} \mathrm{~N}$ values between cetaceans with coastal and pelagic behaviours, which confirm the utility of an isotopic approach to differentiate foraging areas in marine environments of southern South America. Second, we analyse the prey size composition in the zooarchaeological assemblages of pinnipeds to corroborate evidence for increased human predation pressure and whether exploitation depression has occurred. Age/size structure of harvested prey has been widely employed as a measure to discuss the human predation pressure on pinnipeds on the West Coast of North America (Hildebrandt \& Jones, 1992; Jones \& Hildebrandt, 1995; Lyman, 1995, 2003; Colten \& Arnold, 1998; Porcasi et al., 2000; Broughton, 2002; Etnier, 2007; Whitaker \& Hildebrandt, 2011). Following the proposal of Gifford-Gonzalez (2011: 222), we consider 'both regional and supra-regional processes that may affect a taxon possessing a given set of biological parameters'.

Zooarchaeological and stable isotope studies were developed on pinniped skeletal remains recovered in two sites of the Túnel archaeological locality (Figure 1). The stratigraphic sequence of Túnel I and Túnel VII sites span from 6400 to $100 \mathrm{BP}$. The samples analysed are based on the total number of identified specimens value of approximately 66700 remains (Table 1 ). An important consideration for this faunal data is that



Figure 1. Map of the archipelago of Tierra del Fuego and location of Túnel Locality. 
Table 1. Stratigraphical and chronological information (Orquera \& Piana, 1999a: Table 2), and sample sizes of pinniped assemblages of Túnel I and VII sites

\begin{tabular}{|c|c|c|c|}
\hline Sites & Layers & Radiocarbon years BP & NISP \\
\hline \multirow{18}{*}{$\begin{array}{l}\text { Túnel VII } \\
\text { Túnel I }\end{array}$} & $B$ & $100 \pm 45 \mathrm{BP}(\mathrm{AC} 871)$ & 8953 \\
\hline & $\beta$ & $\begin{array}{l}450 \pm 60 \text { BP (Beta4388) } \\
670 \pm 80 \text { BP (AC701) }\end{array}$ & 113 \\
\hline & C1 (floor2) & $\begin{array}{l}1920 \pm 80 \mathrm{BP}(\mathrm{AC} 850) \\
1990 \pm 110 \mathrm{BP}(\mathrm{AC} 851)\end{array}$ & 707 \\
\hline & $\alpha$ & $\begin{array}{l}2660 \pm 100 \text { BP (AC1030) } \\
2690 \pm 80 \text { BP (Beta2516) }\end{array}$ & 780 \\
\hline & $\gamma$ & $2880 \pm 60$ BP (Beta4387) & \\
\hline & $\mathrm{C} 2(\mathrm{XVI})$ & $2930 \pm 100 \mathrm{BP}(\mathrm{AC} 856)$ & \\
\hline & $\begin{array}{l}\text { Level } \pi \\
\text { (trench XIV) }\end{array}$ & & \\
\hline & $\begin{array}{l}\text { C2-3 } \\
\text { Clower }\end{array}$ & $3530 \pm 90 \mathrm{BP}(\mathrm{AC702})$ & \\
\hline & Cbase & & \\
\hline & C3(XVI) & $4300 \pm 80$ BP (Beta4385) & 983 \\
\hline & D Phase VIII & & 3398 \\
\hline & Phase VII & & 4434 \\
\hline & Phase VI & $\begin{array}{l}4590 \pm 130 \mathrm{BP}(\mathrm{AC} 833) \\
5050 \pm 520 \mathrm{BP}(\mathrm{AC} 844)\end{array}$ & 4764 \\
\hline & Phase V & $\begin{array}{l}5840 \pm 185 \text { BP (AC845) } \\
5850 \pm 70 \text { BP (CSIC 308) } \\
5960 \pm 70 \text { BP (CSIC 309) }\end{array}$ & 5067 \\
\hline & Phase IV & & 11346 \\
\hline & Phase III & $5950 \pm 170$ BP (AC838) & $\begin{array}{l}3288 \\
6645\end{array}$ \\
\hline & Phase I & $\begin{array}{l}6150 \pm 220 \text { BP (AC883) } \\
6470 \pm 100 \text { BP (Beta21969) }\end{array}$ & 2223 \\
\hline & $\begin{array}{l}\text { E } \\
\text { Fupper }\end{array}$ & $6200 \pm 100$ BP (Beta3270) & 14038 \\
\hline
\end{tabular}

NISP, number of identified specimens.

there are no significant differences concerning excavation methods and bone preservation between sites. Excavations of these assemblages were made following the same procedures (Orquera \& Piana, 1992).

\section{Stable isotope analysis}

The foraging behaviour of southern fur seals (Arctocephalus) is well known, although studies of foraging locations have focused mainly on female seals (Bonner, 1981; Thompson et al., 2003; Boren, 2010). The annual cycle is generally very similar among southern fur seal species (Bonner, 1981). The sexual size dimorphism in pinnipeds reflects different life history strategies of large male and small female seals (Staniland, 2005). Kernaléguen et al. (2012) also suggest that annual time-budget is an important factor in shaping the sex-related foraging strategies. Although there are no studies using bone tissues in the Southern Hemisphere, sexual-related foraging differences have already been demonstrated in
Arctocephalus species using the isotopic signature of fur seal blood (Cherel et al., 2007) and the isotopic signature of serially sampled whiskers (Kernaléguen et al., 2012). Mean whisker $\delta^{13} \mathrm{C}$ values, which represent a record of feeding habits over several years (like bone tissue), varied with sex in Arctocepbalus gazella: male seals had a $1.1 \%$ o lower value than female seals (Kernaléguen et al., 2012). This variation between sexes is due to the fact that male seals disperse immediately after the harem period, whereas female seals feed dependent young during that time. Parental care explains why female seals spent more time near inshore waters. A foraging behaviour study from satellite tracks of South American fur seals (A.australis) in the Islas MalvinasFalkland Islands (Thompson et al., 2003) shows that female seals forage in inshore waters, normally up to $10 \mathrm{~km}$ from breeding sites, between January and May. From June to December, female seals have a wide distribution into the sea, and they forage mainly in offshore waters (around $100 \mathrm{~km}$ from the breeding site). By contrast, male seals spend more time foraging far from breeding colonies (Schiavini, 1993). Individual seals of this species move from their breeding rookeries with a dispersion pattern, but migratory movements were not recorded (Bonner, 1981; Schiavini, 1993). Nowadays, most breeding colonies are found on isolated rocks. It has been suggested that fur seals prefer more exposed coasts but this could be a recent phenomenon because of the extirpation of more accessible colonies by sealers between the 18 th and 19th centuries (Bonner, 1981).

The foraging behaviour patterns in fur seals could have varied in the past as well-perhaps in response to climate change's impacts of trophic levels of prey, perhaps because of maritime hunting pressure, modifying human predation opportunities. Lyman (2003) has pointed out that the comprehension of human predation opportunities requires that the behaviour of prey species should be understood and, in the case of pinnipeds with high sexual dimorphism, this would include differences in male and female behaviours. These segregating mechanisms in foraging activities between sexes are explored in this paper through $\delta^{13} \mathrm{C}$ and $\delta^{15} \mathrm{~N}$ analyses in bone collagen along the entire archaeological sequence of the Túnel locality.

\section{Materials and methods}

In general, A. australis is smaller than O. flavescens. Therefore, the relative size of bones is different between 
these species, being significantly smaller in A. australis. ${ }^{1}$ Pelvis elements of adult specimens of South American fur seals were considered for the analyses differentiating by laterality and sex (King, 1983). These bones are postcranial elements that allow the determination by sex, which is relevant given that the behaviour and foraging areas vary accordingly (Schiavini, 1993; Burton \& Koch, 1999; Gifford-Gonzalez et al., 2005). Following these criteria, the isotopic analysis developed in this study was carried out entirely with bone remains of South American fur seals and on a sample composed by 21 male seals, 17 female seals and eight specimens without sex determination.

Analyses of $\delta^{13} \mathrm{C}$ and $\delta^{15} \mathrm{~N}$ were conducted on the collagen of 46 samples distributed in three time blocks (Table 1$)$. The early group $(N=20)$ corresponds to the E layer and formation phases I through $\mathrm{V}$ of the $\mathrm{D}$ layer of Túnel I site with a span of 6400-5600 BP (see Orquera \& Piana, 1992 for the definitions of these phases). The middle block is integrated by samples $(N=13)$ obtained in phases VI to VIII of the D layer (between 5000 and $4500 \mathrm{BP})$ and the fourth component of Túnel I (2600 $\mathrm{BP})$. The samples of the latter group $(N=13)$ come from layer B of Túnel VII site, with a radiocarbon age of $100 \pm 45$ BP (AC871) and with a corrected date by dendrochronology of 1835 AD (Orquera \& Piana, 1999a: 84 ), which is previous to the date considered for the beginning of the Industrial Revolution (1850) and consequently to the Suess effect (Misarti et al., 2009).

For extraction of collagen, the bone fragments were cleaned with abrasives and ultrasonic baths. Approximately $1 \mathrm{~g}$ of bone was treated with $\mathrm{NaOH}(0.1 \mathrm{M})$ for $24 \mathrm{~h}$ and then demineralized with $\mathrm{HCl}(2 \%)$ for $72 \mathrm{~h}$, with acid renewed every $24 \mathrm{~h}$. Finally, the fragment was placed another $24 \mathrm{~h}$ in $\mathrm{NaOH}$. The resulting material was dried in the oven for at least $60^{\circ} \mathrm{C}$ (Tykot, 2004). The conservation status of the isotopic signal was evaluated by elemental analysis $(\mathrm{C} / \mathrm{N})$. Dried samples were weighed $(0.5-0.6 \mathrm{mg})$ in thin capsules and measurements of ${ }^{13} \mathrm{C} /{ }^{12} \mathrm{C}$ and ${ }^{15} \mathrm{~N} /{ }^{14} \mathrm{~N}$ relations in the collagen fraction were performed with a Carlo Erba EA1 108 Elemental Analyzer, which is connected to a Thermo Scientific Delta V Advantage continuous flow mass spectrometer through a Thermo Scientific ConFlo IV interface.

\footnotetext{
${ }^{1}$ There is considerable variability in body sizes in the two species of pinnipeds that inhabit the archipelago of Tierra del Fuego, at both the interspecific and intraspecific levels. Schiavini (1990) established that the weight of adult male A. australis ranges between 68 and $81 \mathrm{~kg}$. Female A. australis, however, have a significantly lower weight, with an average of $41 \mathrm{~kg}$ (Schiavini, 1990, 1993). These data are remarkably higher in the case of O. flavescens, where Vaz Ferreira (1979) estimated a range of 300 to $340 \mathrm{~kg}$ for adult male O. flavescens and $144 \mathrm{~kg}$ for adult female O. flavescens (see also Falabella et al., 2009).
}

A Kolmogorov-Smirnov test was employed to check normality for the two variables $\left(\delta^{13} \mathrm{C}\right.$ and $\left.\delta^{15} \mathrm{~N}\right)$, and the modified Levene test was used to evaluate the homogeneity of variances of the samples. Because the distribution of values met the requirements for parametric statistical tests, differences in $\delta^{13} \mathrm{C}$ and $\delta^{15} \mathrm{~N}$ values among assemblages were assessed using analysis of variance and $T$-test to compare two samples. We test the significance at the $\alpha=0.05$ level for all calculations.

\section{Results}

Table 2 provides data about archaeological contexts, sex, collagen yields, $\mathrm{C}: \mathrm{N}$ ratios and collagen isotopic values of analysed specimens. The $\mathrm{C} / \mathrm{N}$ measurements on collagen recorded low variations and are within the accepted range for unaltered samples (2.9-3.6; DeNiro, 1985). Collagen yields are also kept in the range expected for well-preserved bones (van Klinken, 1999). Therefore, despite the chronological differences among the samples, the isotopic signals can be considered as primary.

The overall average for $\delta^{13} \mathrm{C}$ is $-11.8 \%$, with a maximum value of $-10.8 \%$ and a minimum of $-12.8 \%$ o. $\delta^{15} \mathrm{~N}$ values show a greater dispersion with an overall mean of $17.3 \%$, with a maximum value of $18.7 \%$ and a minimum of $15.5 \%$. If we analyse the variability of $\delta^{13} \mathrm{C}$ values among three periods through box-plot graph [Figure 2(a)], we observe that there is no trend over time, and there are no significant differences between the blocks of time $(F=0.33, p=0.72)$. By contrast, the same application for $\delta^{15} \mathrm{~N}$ values [Figure 2(b)] shows a declining trend through later times, showing significant differences between periods $(F=3.26, p=0.04)$.

Because there are differences in behaviour between male and female seals related to the degree of dispersion in Arctocephalus at certain times of the year and foraging practiced by sexes (Schiavini, 1990, 1993), it seems appropriate to analyse the isotopic data discriminated by this variable. Male seals present mean values of $-12.0 \pm 0.4$ in $\delta^{13} \mathrm{C}$ and $17.4 \pm 0.4$ in $\delta^{15} \mathrm{~N}$. The mean values for females are $-11.5 \pm 0.4$ in $\delta^{13} \mathrm{C}$ and $17.1 \pm 0.7$ in $\delta^{15} \mathrm{~N}$. There is a statistically significant difference between means of $\delta^{13} \mathrm{C}$ values of male and female seals ( $t$-test: $3.11, p=0.00)$, whereas there are no recorded statistically significant differences between male and female seals for $\delta^{15} \mathrm{~N}$ mean values $(t=-1.67$, $p=0.12$ ). These differences are consistent with the expectations previously indicated, where female seals usually present higher values than male seals because they are more linked to inshore areas. 
Table 2. Isotopic values for collagen samples of Arctocephalus australis

\begin{tabular}{|c|c|c|c|c|c|c|c|c|c|}
\hline Site & Layer/phase & $\operatorname{Sex}^{a}$ & Lab code (AIE) & $\delta^{13} \mathrm{C}$ & $\delta^{15} \mathrm{~N}$ & $\% \mathrm{C}$ & $\% \mathrm{~N}$ & $\mathrm{C} / \mathrm{N}$ & Collagen yield \\
\hline Túnel I & $E$ & $M$ & 24774 & -12.4 & 17.9 & 41.6 & 14.5 & 3.34 & 19.8 \\
\hline Túnel I & E1 & nd & 24777 & -12.7 & 17.4 & 44.9 & 15.9 & 3.28 & 17.6 \\
\hline Túnel I & E techo & M & 24779 & -11.6 & 16.8 & 43.8 & 15.9 & 3.21 & 18.2 \\
\hline Túnel I & E & nd & 24780 & -11.6 & 17.3 & 40.5 & 14.4 & 3.29 & 19.7 \\
\hline Túnel I & $14 \mathrm{E}$ & nd & 24950 & -11.5 & 17.7 & 41.6 & 15.1 & 3.21 & 15.9 \\
\hline Túnel I & $18 \mathrm{E}$ & nd & 24927 & -12.2 & 17.3 & 43.2 & 15.4 & 3.26 & 14.6 \\
\hline Túnel I & $16 \mathrm{E}$ & M & 24932 & -11.5 & 17.9 & 45.4 & 16.4 & 3.23 & 17.7 \\
\hline Túnel I & E1 & $\mathrm{F}$ & 24935 & -10.8 & 17.2 & 46.2 & 16.8 & 3.21 & 17.5 \\
\hline Túnel I & E sup. & $\mathrm{F}$ & 24942 & -11.9 & 17.4 & 46.2 & 16.7 & 3.23 & 17.5 \\
\hline Túnel I & $E$ & nd & 24944 & -12.4 & 17.2 & 42.1 & 15.2 & 3.23 & 13.8 \\
\hline Túnel I & E1 base & $\mathrm{M}$ & 24945 & -12.4 & 18.0 & 40.6 & 14.8 & 3.20 & 20.4 \\
\hline Túnel I & DI & $\mathrm{F}$ & 24783 & -11.7 & 17.2 & 41.5 & 14.7 & 3.31 & 19.4 \\
\hline Túnel I & DI & $\mathrm{F}$ & 24949 & -11.2 & 17.6 & 43.0 & 15.6 & 3.21 & 19.4 \\
\hline Túnel I & D II & $\mathrm{F}$ & 24931 & -11.3 & 18.1 & 44.0 & 15.9 & 3.22 & 15.5 \\
\hline Túnel I & D II & M & 24934 & -12.0 & 17.6 & 46.5 & 17.0 & 3.19 & 17.5 \\
\hline Túnel I & D IV & $M$ & 24928 & -12.4 & 18.1 & 45.7 & 16.5 & 3.22 & 18.3 \\
\hline Túnel I & D IV & M & 24930 & -12.0 & 17.7 & 45.0 & 16.2 & 3.24 & 19.6 \\
\hline Túnel I & D IV & $M$ & 24940 & -12.5 & 17.5 & 45.5 & 16.5 & 3.22 & 20.8 \\
\hline Túnel I & D IV & $\mathrm{M}$ & 24937 & -11.5 & 17.3 & 45.0 & 16.4 & 3.20 & 19.9 \\
\hline Túnel I & D V & $\mathrm{F}$ & 24947 & -10.9 & 18.1 & 42.0 & 15.2 & 3.21 & 18.1 \\
\hline Túnel I & $\mathrm{DVI}$ & $\mathrm{F}$ & 24951 & -10.9 & 17.5 & 39.1 & 14.2 & 3.22 & 18.2 \\
\hline Túnel I & D VI & $\mathrm{F}$ & 24924 & -11.4 & 16.7 & 41.2 & 14.8 & 3.24 & 16.0 \\
\hline Túnel I & D VI & M & 24938 & -12.1 & 17.0 & 46.4 & 16.8 & 3.22 & 16.9 \\
\hline Túnel I & D VI & M & 24778 & -11.8 & 17.4 & 43.3 & 15.5 & 3.27 & 19.6 \\
\hline Túnel I & $\mathrm{DVI}$ & $M$ & 24781 & -11.4 & 18.1 & 40.9 & 14.7 & 3.24 & 19.4 \\
\hline Túnel I & D VI-VII & $M$ & 24773 & -12.1 & 17.2 & 40.0 & 14.4 & 3.24 & 20.8 \\
\hline Túnel I & D VII & $\mathrm{F}$ & 24784 & -11.9 & 16.4 & 42.1 & 14.9 & 3.30 & 19.9 \\
\hline Túnel I & D VII & $M$ & 24939 & -12.2 & 17.1 & 45.3 & 16.5 & 3.21 & 17.6 \\
\hline Túnel I & D VII & $M$ & 24946 & -10.9 & 17.4 & 42.4 & 15.3 & 3.23 & 19.9 \\
\hline Túnel I & D VIII & $\mathrm{F}$ & 24929 & -11.8 & 16.4 & 46.4 & 16.8 & 3.22 & 18.7 \\
\hline Túnel I & Alfa & nd & 24782 & -12.0 & 16.2 & 34.8 & 11.6 & 3.49 & 17.9 \\
\hline Túnel I & $X$ & nd & 24948 & -11.7 & 18.7 & 40.0 & 14.5 & 3.22 & 20.3 \\
\hline Túnel I & $x$ & nd & 24936 & -12.8 & 18.3 & 43.7 & 15.5 & 3.30 & 11.0 \\
\hline Túnel VII & B390 & $\mathrm{M}$ & 24775 & -12.0 & 16.8 & 46.2 & 16.4 & 3.28 & 23.7 \\
\hline Túnel VII & B536 & $\mathrm{F}$ & 24776 & -11.7 & 17.5 & 41.3 & 14.3 & 3.37 & 24.7 \\
\hline Túnel VII & B130 & $M$ & 24785 & -12.6 & 16.8 & 44.2 & 15.5 & 3.32 & 22.0 \\
\hline Túnel VII & B200 & $\mathrm{M}$ & 24786 & -11.8 & 17.0 & 42.2 & 15.0 & 3.27 & 12.9 \\
\hline Túnel VII & B120 & $\mathrm{F}$ & 24787 & -11.7 & 17.5 & 41.3 & 15.0 & 3.20 & 24.3 \\
\hline Túnel VII & B20 & $\mathrm{F}$ & 24788 & -12.0 & 16.1 & 43.8 & 15.9 & 3.22 & 21.7 \\
\hline Túnel VII & B170 & $M$ & 24789 & -11.7 & 17.2 & 40.8 & 15.1 & 3.14 & 23.9 \\
\hline Túnel VII & B305 & $\mathrm{F}$ & 24791 & -11.6 & 16.7 & 44.5 & 16.1 & 3.23 & 24.9 \\
\hline Túnel VII & B465 & $\mathrm{M}$ & 24792 & -12.1 & 18.1 & 40.3 & 14.4 & 3.26 & 19.0 \\
\hline Túnel VII & B225 & $\mathrm{M}$ & 24925 & -12.4 & 17.2 & 45.9 & 16.7 & 3.21 & 22.2 \\
\hline Túnel VII & B205 & $\mathrm{F}$ & 24926 & -11.5 & 17.9 & 42.0 & 15.2 & 3.22 & 18.5 \\
\hline Túnel VII & T.P. & $\mathrm{F}$ & 24933 & -12.3 & 15.5 & 46.4 & 16.7 & 3.23 & 21.2 \\
\hline Túnel VII & T.P. & F & 24943 & -11.6 & 17.1 & 44.5 & 16.2 & 3.21 & 18.9 \\
\hline
\end{tabular}

and, not determined; $F$, female; $M$, male.

To summarise, on the one hand, there is no variation in the values of $\delta^{13} \mathrm{C}$, whereas there is a decrease in $\delta^{15} \mathrm{~N}$ values towards later stages. On the other hand, the values differentiated by sex show that there is a significant difference in $\delta^{13} \mathrm{C}$, whereas no statistically significant difference in $\delta^{15} \mathrm{~N}$ is recorded. This leads us to analyse the isotopic data considering both factors simultaneously.

Regarding variations of $\delta^{13} \mathrm{C}$ values, male seals maintain a stable trend among the three temporal periods, whereas female seals have a tendency towards more negative values at later times [Table 3 ; Figure $3(\mathrm{a})]$. Male and female seals present significant differences in diet in the early period $(p=0.00)$, whereas there are no statistical differences between sexes in the middle $(p=0.45)$ and late $(p=0.08)$ periods. These results suggest that seal foraging behaviour varied along time, showing more intensive activities in inshore waters by female seals than male seals at the beginning of the sequence. It is not possible to differentiate foraging patterns between sexes in later sections of the archaeological sequence. In relation to $\delta^{15} \mathrm{~N}$ values, there are no statistical differences between male and female seals in different time periods, confirming the trends towards decreased values in later times in both sexes [Table 3; Figure 3(b)]. 

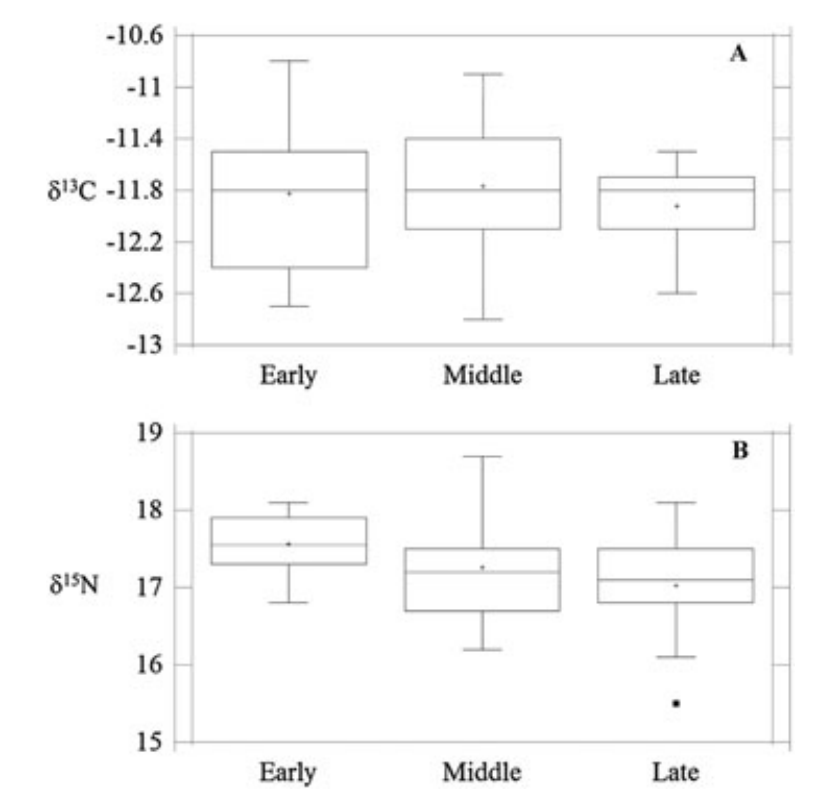

Figure 2. Box-plots of bone collagen $\delta^{13} \mathrm{C}$ and $\delta^{15} \mathrm{~N}$ values by time period.

\section{Size composition of exploited prey}

\section{Materials and methods}

Size and age composition of exploited prey has been an important aspect to support evidence for hunter-gatherer predation pressure on pinnipeds (Schiavini, 1990, 1993; Hildebrandt \& Jones, 1992; Jones \& Hildebrandt,

Table 3. Mean values and standard deviations for time periods and sexes

\begin{tabular}{|c|c|c|c|c|c|c|}
\hline \multicolumn{7}{|c|}{$\delta^{13} \mathrm{C}$} \\
\hline $\begin{array}{l}\text { Time } \\
\text { period }\end{array}$ & Sex & $N$ & Mean & $\begin{array}{l}\text { Standard } \\
\text { deviation }\end{array}$ & $\begin{array}{l}\text { Maximum } \\
\text { value }\end{array}$ & $\begin{array}{l}\text { Minimum } \\
\text { value }\end{array}$ \\
\hline \multirow[t]{3}{*}{ Early } & Female & 6 & -11.3 & 0.43 & -10.8 & -11.9 \\
\hline & Male & 9 & -12.0 & 0.41 & -11.5 & -12.5 \\
\hline & Unknown & 5 & -12.1 & 0.51 & -11.5 & -12.7 \\
\hline \multirow[t]{3}{*}{ Middle } & Female & 4 & -11.5 & 0.45 & -10.9 & -11.9 \\
\hline & Male & 6 & -11.7 & 0.50 & -10.9 & -12.2 \\
\hline & Unknown & 3 & -12.1 & 0.56 & -11.7 & -12.8 \\
\hline \multirow[t]{2}{*}{ Late } & Female & 7 & -11.6 & 0.28 & -11.3 & -12.1 \\
\hline & Male & 6 & -11.9 & 0.34 & -11.5 & -12.4 \\
\hline \multicolumn{7}{|c|}{$\delta^{15} \mathrm{~N}$} \\
\hline \multirow[t]{3}{*}{ Early } & Female & 6 & 17.6 & 0.41 & 18.1 & 17.2 \\
\hline & Male & 9 & 17.6 & 0.40 & 18.1 & 16.8 \\
\hline & Unknown & 5 & 17.4 & 0.19 & 17.7 & 17.2 \\
\hline \multirow[t]{3}{*}{ Middle } & Female & 4 & 16.7 & 0.51 & 17.5 & 16.4 \\
\hline & Male & 6 & 17.3 & 0.39 & 18.1 & 17.0 \\
\hline & Unknown & 3 & 17.7 & 1.34 & 18.7 & 16.2 \\
\hline \multirow[t]{2}{*}{ Late } & Female & 7 & 16.9 & 0.85 & 17.9 & 15.5 \\
\hline & Male & 6 & 17.1 & 0.48 & 18.1 & 16.8 \\
\hline
\end{tabular}

Copyright (C) 2013 John Wiley \& Sons, Ltd.

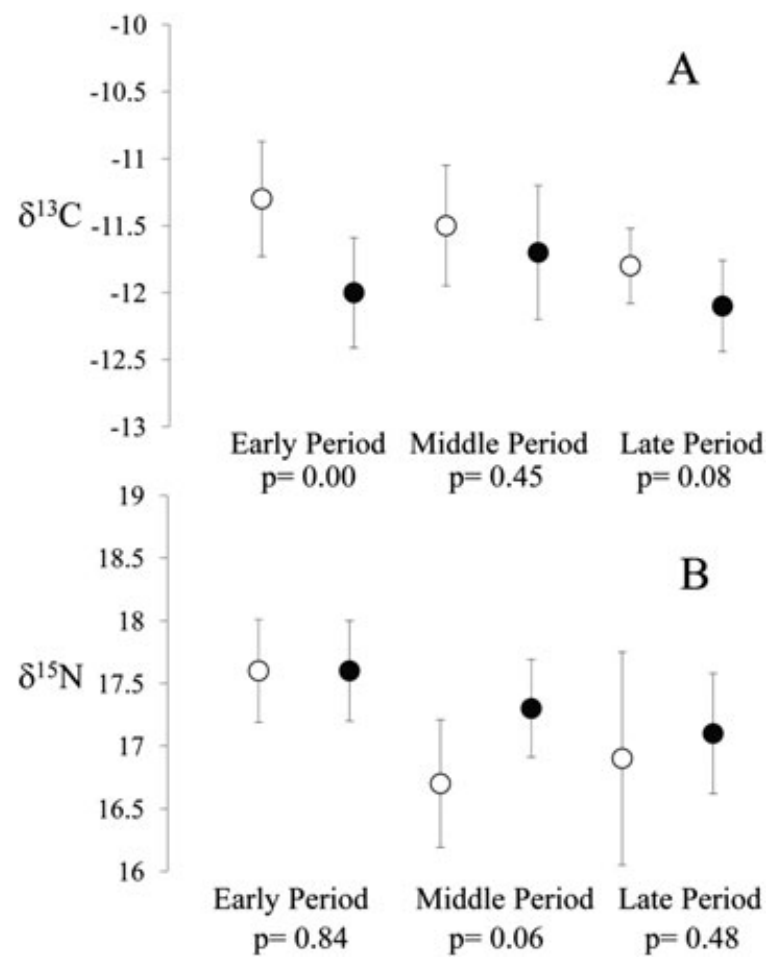

Figure 3. Comparisons of bone collagen $\delta^{13} \mathrm{C}$ and $\delta^{15} \mathrm{~N}$ mean values by time period for female (open circles) and male seals (solid circles).

1995; Lyman, 1995, 2003; Colten \& Arnold, 1998; Porcasi et al., 2000; Broughton, 2002; Etnier, 2007; Whitaker \& Hildebrandt, 2011). Although it is a study in progress (L'Heureux \& Borella, 2011), growth curves for postcranial bones to establish ages of pinnipeds have been partially defined for the species which inhabit coastal environments of Patagonia and Tierra del Fuego. To analyse whether there was variability in prey sizes, the maximum length of mandibles were measured (Legoupil, 1989). The advantage of this bone versus postcranial elements is that it allows an unambiguous identification for each species and sex. A total of 302 mandibles corresponding to both sexes of A. australis were measured; only complete and wellpreserved specimens were considered for measurements. Normality and homogeneity of variances of samples were respectively checked by KolmogorovSmirnov and Levene tests. Because the distribution of values met the requirements for parametric statistical tests, differences between assemblages were assessed using analysis of variance. Consistent with foraging theory and models suggesting over-exploitation (e.g. Broughton, 2002), our expectation is that resource depression will lead to a decline of the average size ratio of the exploited prey through time.

Int. J. Osteoarchaeol. 24: 231-244 (2014) 


\section{Results}

The results are shown in Table 4, which are statistically differentiated for different time periods and by sex categories. General mean values indicate a reduction in the maximum length of the mandibles and therefore in the sizes of the captured prey (Figure 4): the average value for the early period is $140.3 \mathrm{~mm}$, reducing to $134.4 \mathrm{~mm}$ in the middle period and $130.0 \mathrm{~mm}$ at the later times of the sequence. There is a statistically significant difference between the assemblages $(F=5.53$, $p=0.00)$. The decrease in the size of the mandibles is more remarkable in female seals than in male seals (Table 4 ). In the early period, female seals present an average value of $136.1 \mathrm{~mm}$, reducing to 129.2 and $116.5 \mathrm{~mm}$ in the middle and late periods, respectively. Male seals also show a decrease between early $(141.5 \mathrm{~mm})$ and middle $(136.9 \mathrm{~mm})$ periods, but they present a greater value in later times $(146.2 \mathrm{~mm})$. The cause of the increase in mean size of males is not clear but may be an artefact of small sample size.

\section{Discussion and conclusions}

Previous zooarchaeological studies on pinniped remains of Túnel locality have suggested that the predation of A. australis has been focused on male seals, which would not have generated an impact on the demographic structure of this resource and therefore on their abundance in the environment across the occupational sequence (Schiavini, 1990, 1993; Orquera \& Piana, 1999a). Nevertheless, more recent studies have shown a regional long-term variation from the compositions of several zooarchaeological assemblages of the Beagle Channel, including a significant decrease in the relative importance of pinnipeds since 5500-5000 BP (Zangrando, 2009a, 2009b; Zangrando et al., 2010;


Figure 4. Mean values of maximum lengths of fur seal mandibles for time periods.

Tivoli \& Zangrando, 2011). Resource depression may have been caused by several mechanisms (Lyman, 2003; Betts et al., 2011), including changes in prey behaviour or changes in the behaviour of human predators (e.g. population expansion and variations in technology). At the beginning of this paper, we raised two possible explanations that could account for long-term variations in the representations of pinnipeds observed in the zooarchaeological record of the Beagle Channel region: (i) variations in foraging habits of pinnipeds that would lead to changes in the degree of predictability or access to the resource or (ii) resource depression or declines in prey capture rates that stem from the activities of human predation. The analyses developed in this paper suggest that both explanations are relevant to our research question.

Stable isotope analyses show that the foraging behaviour of seals showed changes from the early moments to the later times of the archaeological sequence, thus human predation opportunities on this resource could have varied along time. At the beginnings of the sequence, between 6400-5500 BP, female

Table 4. Mean values and standard deviations of maximum lengths of fur seal mandibles for time periods and sexes

\begin{tabular}{|c|c|c|c|c|c|c|}
\hline Time period & Sex categories & $\mathrm{N}$ & Mean & Standard deviation & Maximun value & Minimum value \\
\hline \multirow[t]{4}{*}{ Early (6200-4300 BP) } & Female & 36 & 136.1 & 13.4 & 163.0 & 115.0 \\
\hline & Male & 179 & 141.5 & 15.9 & 170.0 & 96.0 \\
\hline & Unknown sex & 15 & 135.8 & 17.1 & 162.0 & 104.0 \\
\hline & All specimens & 230 & 140.3 & 15.7 & 170.0 & 96.0 \\
\hline \multirow{4}{*}{ Middle (4300-1990 вP) } & Female & 12 & 129.2 & 19.3 & 173.0 & 98.0 \\
\hline & Male & 36 & 136.9 & 14.7 & 165.0 & 113.0 \\
\hline & Unknown sex & 12 & 132.1 & 15.9 & 156.0 & 110.0 \\
\hline & All specimens & 60 & 134.4 & 16.0 & 173.0 & 98.0 \\
\hline \multirow{4}{*}{ Late (100 BP) } & Female & 4 & 116.5 & 14.4 & 129.0 & 104.0 \\
\hline & Male & 5 & 146.2 & 12.9 & 168.0 & 136.0 \\
\hline & Unknown sex & 3 & 121.0 & 15.9 & 132.0 & 103.0 \\
\hline & All specimens & 12 & 130.0 & 19.3 & 168.0 & 103.0 \\
\hline
\end{tabular}


seals foraged mainly in coastal waters, showing significant differences with the dietary pattern of male seals. Assuming that fur seal's breeding colonies were on island or islets in the outer parts of the Fuegian archipelago and that male seals were more dispersed in the marine environment outside the Harem period, the hunting opportunities of female seals were less probable than for male seals. Nevertheless, since 5000 BP, $\delta^{13} \mathrm{C}$ values of female and male seals became closer. This variation may have been involved a change in dietary habits in female seals and a potential expansion in foraging ranges from breeding areas-although not necessary to the same degree male seals. Through this expansion, a greater dispersion in the marine environment of female individuals would have happened, changing the probabilities of predation by human groups. Two different arguments, both natural and cultural, could be raised to explain this change in foraging behaviour. Regarding the former, recent studies have demonstrated that changes in sea surface temperature did not play a significant role in fur seal behaviour change in waters of the Beagle Channel (Saporiti et al., 2013). Nevertheless, variations in marine primary productivity could also influence the foraging patterns of these animals (Newsome et al., 2007), and this possibility should be evaluated in the future (Saporiti et al., 2013). This seems to be particularly important for the general variation observed in $\delta^{15} \mathrm{~N}$ : there is a trend in the nitrogen isotopic compositions over time, indicating a slight decline in trophic level of both male and female seals.

The other potential argument is that human predation increased through time near breeding areas, leading to changes in the behaviour of southern fur seals (Lyman, 2003; Betts et al., 2011). A process of avoiding areas frequented by human predators would explain why female seals may have changed their foraging behaviour. Although more stable isotope analyses are required to assess paleoenvironmental factors, the second argument would be evaluated through the archaeological evidence. To determine whether there was an increase of human predation on pinnipeds becomes a key issue of this discussion.

The results presented in this paper show a decrease in size pattern of the prey population, which is expected with an increase in harvest intensity (Hildebrandt \& Jones, 1992; Jones \& Hildebrandt, 1995; Lyman, 1995, 2003; Colten \& Arnold, 1998; Porcasi et al., 2000; Broughton, 2002; Etnier, 2007; Whitaker \& Hildebrandt, 2011). However, to assess that the age structure of seal populations changed throughout time by human predation, a more detailed analysis of age profiles is needed. To explore this aspect, next, we will apply the methodological approach proposed by Etnier (2007: 199), which consists of using age-at-death data to generate age frequency histograms or harvest profiles for different temporal units from the archaeological sites. Our expectation is that if there was a net increase in seal predation, a decrease on median age should be recorded. Taking into account that the age estimates for postcranial remains are less accurate than those from teeth, we use the age-at-death profiles determined for that skeletal element by Schiavini (1990). We compare this information between two temporal units defined in this paper: previously to $5000 \mathrm{BP}(6400-5500 \mathrm{BP})$ and afterwards to that point in time (5000-2600 BP). The number of determinations for Túnel VII were significantly low $(n=4)$, and it does not have statistical value for this comparative propose (Schiavini, 1990).

There are interesting differences between those time periods. Figure 5 shows that male seals are represented with $80 \%$ for $6400-5500 \mathrm{BP}$, whereas this sex category reflects a decrease towards $63 \%$ for 5000-2600 BP. In contrast, an increase in female seals is recorded in time but more significant was the rise in the proportion of individuals younger of the year (YOY) from $5 \%$ to $17 \%$. Age-at-death analyses show that median age of both sexes decline over time, especially in female seals (Figure 6). The cause of the decrease in male seals is clearly driven by the augment in the proportion of YOY. In the female case, the decline in median age is due to an increase in predation on subadults with respect to earlier times. Taking into account that bone specimens of pinnipeds recovered in archaeological sites do not represent long-distance transports of carcasses, it is interesting to note the increase in the proportion of YOY, which is expected to be positively correlated with the proximity to breeding colonies.

It has been proposed that the breeding colonies of fur seals were beyond the reach of human groups of the Beagle Channel (Schiavini, 1993). From our perspective, it is difficult to attribute a decrease in the availability of A. australis as the cause of these changes, using only the Beagle Channel as the frame of discussion. In this sense, the current knowledge of coastal archaeology of Fuegian archipelago as a whole lets some comment on the previous sustainability argument, in which the use of pinnipeds was seen in such a way that allowed stable harvest rates into perpetuity (Schiavini, 1993; Orquera \& Piana, 1999a). Research subsequent to Schiavini's work shows that many peripheral sectors of the Fuegian archipelago were inhabited by hunter-gatherer groups, and the breeding colonies were not virtually beyond the reach of human groups. 


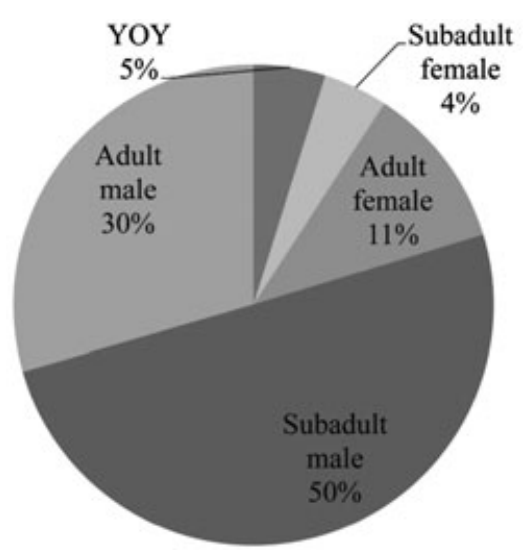

$\mathrm{MNI}=207$

6400-5500 BP

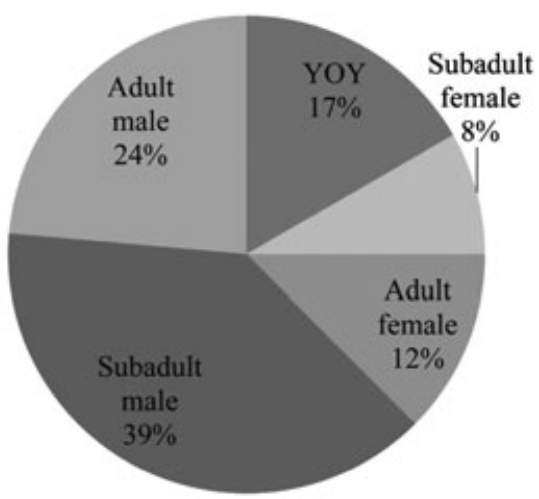

$\mathrm{MNI}=70$

5000-2600 BP

Figure 5. Pie diagrams with proportions of younger of the year (YOY), subadult male or female and adult male or female for zooarchaeological assemblages of early and middle temporal periods; data was taken from Schiavini (1990).

Figure 7 shows locations of rockeries and human occupations in offshore settings, especially in Península Mitre, Staten Island and Cape Horn. In Valentín Bay (southwest coast of Península Mitre), technological (harpoon points) and faunal evidence for the exploitation of pinnipeds are present in occupations with chronologies between 5900 and 4360 BP (Tessone et al.,



Figure 6. Distribution of age estimates for Arctocephalus australis teeth from Túnel I site for early and middle temporal periods; data was taken from Schiavini (1990).
2007; Zangrando et al., 2009; Vázquez et al., 2011). The association of this bone technology with the faunal remains of pinnipeds was also recorded in many later sites of this bay (Vidal, 1985; Scheinsohn, 1997, 2011; Zangrando et al., 2009; Vázquez et al., 2011). Pinniped bones are also abundant in many of Late Holocene sites on the north coast of Península Mitre (Lanata, 1990, 1993; Muñoz, 1996, 2004, 2005). Archaeological studies have reported occupations between approximately 2700 and 1500 BP in Staten Island (Horwitz \& Weissel, 2011: Table 1), where numerous colonies of A.australis and O.flavescens are currently located (Falabella et al., 2009). The analyses of zooarchaeological assemblages from Crossley Bay I site, located in the western part of the island, showed a systematic exploitation of pinnipeds along the entire sequence of this site, and the remains are attributable to eight pups, six juveniles and nine adults (Horwitz \& Weissel, 2011: Table 3). Legoupil (1993) has reported late occupations in the archipelago of Cape Horn, where the two species of pinnipeds were regularly exploited. Numerous historical documents also indicate the presence of maritime hunter-gatherers in the islands of the archipelago of Cape Horn in the 19th century (Orquera \& Piana, 1999b: 86). Although it remains unclear how intensively marginal sectors of the Fuegian archipelago were occupied by maritime hunter-gatherers (Zangrando et al., 2009) and it is not still possible to confirm hunting on rookeries by these societies, the breeding areas of fur seals do not appear to have been beyond of the reach of hunter-gatherer groups since $5000 \mathrm{BP}$.

To conclude, although predation of A. australis has been focused on male seals, the decrease in size and 


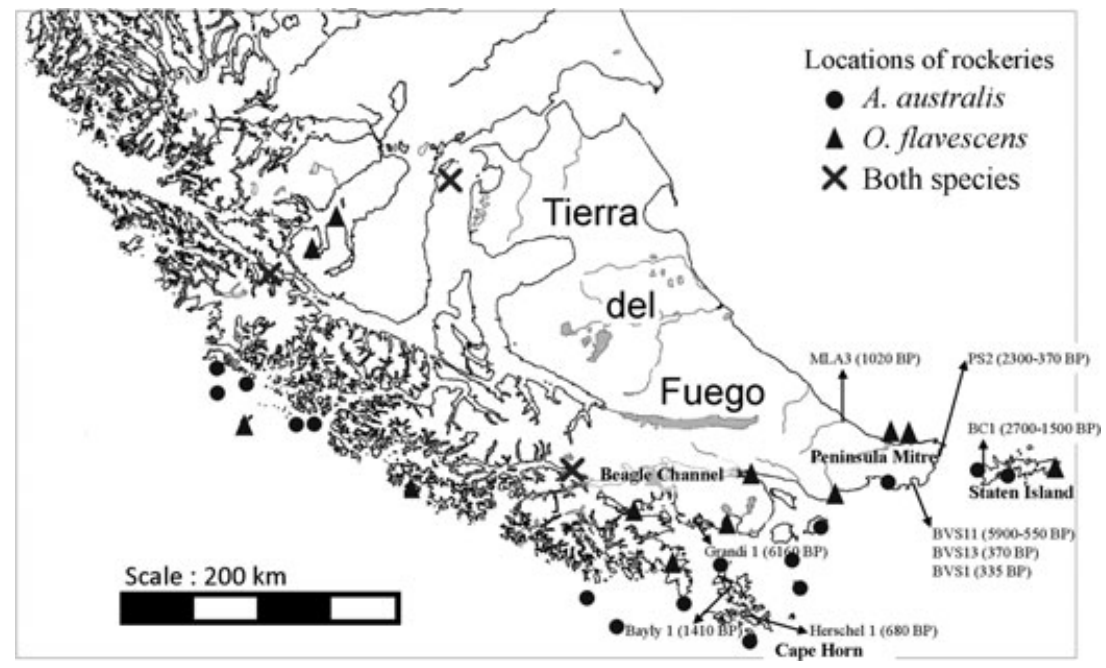

Figure 7. Locations of rockeries, archaeological sites and radiocarbon dates in peripheral sectors of the Fuegian archipelago. Abbreviations: BVS (Valentin Bay sites), BC1 (Crosseley Bay site 1), MLA3 (María Luisa site 3) and PS2 (Punta Sorpresa site 2).

in median age of individuals of southern fur seals in the archaeological record of Túnel locality suggests that harvest intensity increased over time. The change of the initial foraging behaviour of seals could be interpreted as a strategy of avoiding areas frequented by human predators, although it does not appear to have been successful in the long term. Assuming that age classes of pinnipeds are represented in the archaeological record in proportion to their past availability (Etnier, 2007), we propose that a resource depression of pinnipeds took place, probably because of human demographic growth and population expansion on the Fuegian archipelago.

\section{Acknowledgements}

We are very grateful to Hein Bjerck, Heidi Mjelva Breivik, Enrique Crespo, Dánae Fiore, Seth Newsome, Augusto Tessone, Angélica Tivoli and Andrew Ugan for their valuable comments on the manuscript. Mariano Diez helped us with the statistical analyses. We would also like to thank to three anonymous reviewers for their comments. This research was supported by PIP 0395/10 (CONICET), PICT2010-1322 (FONCYT) and the 'Marine Ventures' Project (Research Counsil of Norway no. 208828). Excavations and research in Túnel VII site were conducted jointly with J. Estévez Escalera and A. Mitja Vila. The authors are responsible for the contents of this paper.

\section{References}

Betts MW, Maschner HDG, Lech V. 2011. A 4500-yeartime-series of otariid abundance on Sanak Island, Western Gulf of Alaska. Human Impacts on Seals, Sea Lions, and Sea Otters. Integrating Archaeology and Ecology in the Northeast Pacific, Braje TJ, Rick T (eds). University of California Press Berkeley: Los Angeles and London; 93-110.

Bonner N. 1981. Southern fur seals. Arctocephalus (Geoffroy Saint-Hilarie and Cuvier, 1826). Handbook of Marine Mammals, Vol. 1: The Walrus, Sea Lions, Fur Seals and Sea Otter, Ridgway SH, Harrison RJ (eds). Academic Press: London, 161-208.

Boren L. 2010. Diet of New Zealand fur Seals (Arctocepbalus Forsteri): A Summary. DOC Research \& Development Series 319. New Zealand Department of Conservation: Wellington, New Zealand.

Broughton JM. 2002. Prey spatial structure and behavior affect archaeological tests of optimal foraging models: Examples from the Emeryville Shellmound vertebrate fauna. World Archaeology 34: 60-83.

Burton K, Koch P. 1999. Isotopic tracking of foraging and long-distance migration in northeastern Pacific pinnipeds. Oecologia 119: 578-585.

Burton K, Snodgrass J, Gifford-Gonzalez D, Guilderson T, Brown T, Koch P. 2001. Holocene changes in the ecology of northern fur seals: Insights from stable isotopes and archaeofauna. Oecologia 128: 107-115.

Carrara L. 1952. Lobos Marinos, Pingüineras y Guaneras de la Costa del Litoral Marítimo e Islas Adyacentes de la República Argentina. Facultad de Ciencias Veterinarias, UNLP: La Plata.

Cherel Y, Hobson KA, Guinet C, Vanpe C. 2007. Stable isotopes document seasonal changes in trophic niches 
and winter foraging individual specialization in diving predators from the Southern Ocean. Journal of Animal Ecology 76: 826-836.

Colten RH, Arnold JE. 1998. Prehistoric marine mammal hunting on California's northern Channel Islands. American Antiquity 63: 679-701.

DeNiro MJ. 1985. Postmortem preservation and alteration of in vivo bone collagen isotope ratios in relation to paleodietary reconstruction. Nature 317: 806-809. DOI: 10.1038/317806a0

Etnier MA. 2007. Defining and identifying sustainable haversts of resources: Archaeological examples of pinniped harvests in the eastern North Pacific. Journal for Nature Conservation 15: 196-207. DOI:10.1016/j. jnc.2007.04.003

Falabella V, Campagna C, Croxall J. 2009. Atlas del Mar Patagónico. Especies y espacios. Wildlife Conservation Society y BirdLife International: Buenos Aires.

Fitz-Roy R. 1839. Proceedings of the Second Expedition (1831-1836) Under the Command of Captain Fitz-Roy (R. N.). En Narrative of the Surveying Voyages of His Majesty's Ships Adventure and Beagle Between the Years 1826 and 1836 (...). Henry Colburn: London.

Gifford-Gonzalez D. 2011. Holocene Monterey Bay fur seals. Human Impacts on Seals, Sea Lions, and Sea Otters. Integrating Archaeology and Ecology in the Northeast Pacific, Braje TJ, Rick T (eds). University of California Press Berkeley: Los Angeles and London; 221-242.

Gifford-Gonzalez D, Newsome S, Koch P, Guilderson T, Snodgrass J, Burton R. 2005. Archaeofaunal insights on pinniped-human interactions in the Northeastern Pacific. The Exploitation and Cultural Importance of Sea Mammals, Monks G (ed.). Oxbow Books: Oxford $_{i}$ 19-38.

Grandi MF, Dans SL, Crespo EA. 2008 Social composition and spatial distribution of colonies in an expanding population of South American sea lions. Journal of Mammalogy 89: 1218-1228.

Gusinde M. 1986. Los indios de Tierra del Fuego, Tomo II: Los Yámana. CAEA: Buenos Aires.

Hildebrandt WR, Jones TL. 1992. Evolution of marine mammal hunting: A view from the California and Oregon coasts. Journal of Antbropological Archaeology 11:360-401.

Horwitz V, Weissel M. 2011. Arqueología de Isla de los Estados: la frontera de la abundancia. Los cazadoresrecolectores del extremo oriental fueguino. Arqueología de Península Mitre e Isla de los Estados, Zangrando AF, Vázquez M, Tessone A (eds). Sociedad Argentina de Antropología: Buenos Aires; 271-286.

Hyades PD, Deniker J. 1891. Anthropologie et Ethnographie. En Mission Scientifique du Cap Horn 1882-1883, Vol. VII. Ministère de la marine et des colonies: París.

Jones TL, Hildebrandt WR. 1995. Reasserting a prehistoric tragedy of the Commons: A reply to Lyman. Journal of Antbropological Archaeology 14: 78-98.
Kernaléguen L, Cazelles B, Arnould JPY, Richard P, Guinet C, Cherel Y. 2012. Long-term species, sexual and individual variations in foraging strategies of fur seals revealed by stable isotopes in whiskers. PLoS ONE 7(3): e32916. DOI: 10.1371/journal.pone.0032916

King J. 1983. Seals of the World. Oxford University Press: Londres.

Lanata JL. 1990. Humans and terrestrial and sea mammals at Península Mitre, Tierra del Fuego. Hunters of the Recent Past, Davis LB, Reeves BOK (eds). Unwin Hyman: London; 400-406.

Lanata JL. 1993. Estados alterados: procesos de formación y conjuntos faunísticos en Rancho Donata, Tierra del Fuego. Explotación de Recursos Faunísticos en Sistemas Adaptativos Americanos. Arqueología Contemporánea 4: 163-176.

Legoupil D. 1989. Ethno-archéologie dans les archipels de Patagonie: les nómades marines de Punta Baja. Editions Recherche sur les Civilisations no. 84: París.

Legoupil D. 1993. El archipiélago del cabo de Hornos y la costa sur de la isla Navarino:poblamiento y modelos económicos. Anales del Instituto de la Patagonia (Serie Ciencias Humanas) 22: 101-121.

Legoupil D, Fontugne M. 1997. El poblamiento marítimo de los archipiélagos de Patagonia: núcleos antiguos y dispersión reciente. Anales del Instituto de la Patagonia (Serie Ciencias Humanas) 25: 75-87.

L'Heureux GL, Borella F. 2011. Guía Osteométrica para el estudio de elementos óseos de Otaria flavescens. Universidad Nacional del Centro de la Provincia de Buenos Aires: Buenos Aires.

Lyman RL. 1995. On the evolution of marine mammal hunting on the west coast of North America. Journal of Antbropological Archaeology 14: 45-77.

Lyman RL. 2003. Pinniped behavior, foraging theory, and the depression of metapopulations and nondepression of a local population on the southern Northwest Coast of North America. Journal of Antbropological Archaeology 22: 376-388.

Misarti N, Finney B, Mascher H, Wooller M. 2009. Changes in northeast Pacific marine acosystems over the last 4500 years: Evidence from stable isotope analysis of bone collagen from archaeological middens. The Holocene 19: 1139-1151. DOI: $10.1177 / 0959683609345075$

Muñoz AS. 1996. Explotación de pinnípedos en la costa atlántica de Tierra del Fuego. Arqueología 6: 199-222.

Muñoz AS. 2004. Mammal exploitation in the insular environments of southern South America. Zooarchaeology of South America, Mengoni Goñalons GL (ed.) BAR International Series 1298. Archaeopress, Publishers of British Archaeological Reports: Oxford, 123-137.

Muñoz AS. 2005. Zooarqueología del sector atlántico de la Isla Grande de Tierra del Fuego. Relaciones de la Sociedad Argentina de Antropología XXX: 59-77.

Newsome SD, Clementz MT, Koch PL. 2010. Using stable isotope biogeochemistry to study marine mammal ecology. Marine Mammal Science 26(3): 509-572. DOI: 10.1111/j.1748-7692.2009.00354.x 
Newsome SD, Etnier MA, Kurle CM, Waldbauer JR, Chamberlain CP, Koch PL. 2007. Historic decline in primary productivity in western Gulf of Alaska and eastern Bering Sea: Isotopic analysis of northern fur seal teeth. Marine Ecology Progress Series 332: 211-214.

Orquera LA. 2002. The late nineteenth-century crisis in the survival of the Magellan-Fueguian litoral natives. Archaeological and Anthropological Perspectives on the Native Peoples of Pampa, Patagonia, and Tierra del Fuego to the Nineteenth Century, Briones C, Lanata JL (eds). Bergin \& Garvey: Londres; 145-158.

Orquera LA, Piana EL. 1986. Composición topológica y datos tecnomorfológicos y tecnofuncionales de los distintos conjuntos arqueológicos del sitio Túnel I (Tierra del Fuego). Relaciones de la Sociedad Argentina de Antropología XVII: 201-239.

Orquera LA, Piana EL. 1992. Un paso hacia la resolución del palimpsesto. Análisis espacial en la Arqueología Patagónica, Borrero L, Lanata JL (eds). Ayllu: Buenos Aires; 21-52.

Orquera LA, Piana EL. 1999a. Arqueología de la región del canal Beagle (Tierra del Fuego, República Argentina). Sociedad Argentina de Antropología: Buenos Aires.

Orquera LA, Piana EL. 1999b. La vida material y social de los Yámana. Editorial Universitaria de Buenos Aires: Buenos Aires.

Orquera LA, Piana EL. 2009. Sea nomads of the Beagle Channel in southernmost South America: Over six thousand years of coastal adaptation and stability. Journal of Island \& Coastal Archaeology 4: 1-21. DOI: 10.1080/ 15564890902789882. 2008

Porcasi JF, Jones TL, Raab LM. 2000. Trans-Holocene marine mammal exploitation on San Clemente Island, California: A tragedy of the commons revisited. Journal of Anthropological Archaeology 19: 200-220.

Riccialdelli L, Newsome SD, Fogel ML, Goodall RNP. 2010. Isotopic assessment of prey and habitat preferences of cetacean community in the southwertern South Atlantic Ocean. Marine Ecology Progress Series 418: 235-248. DOI: 10.3354/meps08826

Rick TC, Braje TJ, DeLong RL. 2011. People, pinnipeds, and sea otters of the Northeast Pacific. Human Impacts on Seals, Sea Lions, and Sea Otters. Integrating Archaeology and Ecology in the Northeast Pacific, Braje TJ, Rick T (eds). University of California Press Berkeley: Los Angeles and London; 1-17.

San Román M. 2008. La explotación de mamíferos en el sitio Bahía Buena: economía de canoeros tempranos de Patagonia (Estrecho de Magallanes). Arqueología de Fuego-Patagonia. Levantando piedras, desenterrando huesos... y desvelando arcanos, Morello F, Martinic M, Prieto A, Bahamonde G (eds). Ediciones CEQUA: Punta Arenas; 295-310.

Saporiti F, Bala LO, Crespo EA, Gómez Otero J, Zangrando AF, Aguilar A, Cardona L. 2013. Changing patterns of marine resource exploitation by hunter-gatherers throughout the late Holocene of Argentina are uncorrelated to sea surface temperature. Quaternary International 299: 108-115. DOI: 10.1016/j.quaint.2013.03.026

Scheinsohn V. 1997. Explotación de materias primas óseas en la Isla Grande de Tierra del Fuego. Unpublished PhD dissertation. Facultad de Filosofía y Letras, Universidad de Buenos Aires, Buenos Aires.

Scheinsohn V. 2011. El trabajo del hueso en el fin del mundo: tecnología ósea en Bahía Valentín. Los cazadores-recolectores del extremo oriental fueguino. Arqueología de Península Mitre e Isla de los Estados, Zangrando AF, Vázquez M, Tessone A (eds). Sociedad Argentina de Antropología: Buenos Aires; 271-286.

Schiavini AM. 1990. Estudio de la relación entre el hombre y los pinnípedos en el proceso adaptativo humano del canal Beagle (Tierra del Fuego, Argentina). Unpublished PhD dissertation. Facultad de Ciencias Exactas y Naturales, Universidad de Buenos Aires, Buenos Aires.

Schiavini AM. 1993. Los lobos marinos como recurso para cazadores-recolectores marinos: el caso de Tierra del Fuego. Latin American Antiquity 4: 346-366.

Sielfeld W. 1983. Mamíferos Marinos de Chile. Universidad de Chile: Santiago.

Sielfeld W, Venegas C, Atalah A, Torres J. 1978. Prospección de otáridos en las costas de Magallanes. Anales del Instituto de la Patagonia 9: 157-169.

Staniland I. 2005. Sexual segregation in seals. Sexual segregation in vertebrates: ecology of the two sexes, Ruckstuhl KE, Neuhaus P (eds.). Cambridge University Press: Cambridge; $53-73$.

Tessone A, Vázquez M, Zangrando AF, Ceraso A, Ponce F, Sosa L. 2007. Recientes excavaciones en bahía Valentín (Tierra del Fuego). Actas del XVI Congreso Nacional de Arqueología Argentina, Tras las huellas de la Materialidad III: 453-459.

Thompson D, Moss SEW, Lovell P. 2003. Foraging behaviour of South American Fur seals Arctocephalus australis: Extracting fine scale foraging behaviour from satellite tracks. Marine Ecology Progress Series 260: 285-296.

Tivoli A, Zangrando AF. 2011. Subsistence variations and landscape use among maritime hunter-gatherers. A zooarchaeological analysis from the Beagle Channel (Tierra del Fuego, Argentina). Journal of Archaeological Science 38: 1148-1156.

Tykot RH. 2004. Stable isotopes and diet: You are what you eat. Physics Methods in Archaeometry. Proceedings of the International School of Physics "Enrico Fermi", Martini M, Milazzo M, Piacentini M (eds). Societá Italiana di Fisica: Bologna; 433-444.

Van Klinken GJ. 1999. Bone collagen quality indicators for paleodietary and radiocarbon measurements. Journal of Archaeological Science 26: 687-695.

Vaz Ferreira R. 1979. South American fur seal. FAO Fisheries Series 2: 9-12.

Vázquez M, Zangrando AF, Tessone A, Ceraso A. 2011. Investigaciones arqueológicas recientes en la costa suroriental de Península Mitre. Los cazadoresrecolectores del extremo oriental fueguino. Arqueología 
de Península Mitre e Isla de los Estados, Zangrando AF, Vázquez M, Tessone A (eds). Sociedad Argentina de Antropología, Buenos Aires; 203-230.

Vidal H. 1985. Los conchales de Bahía Valentín. Unpublished Master dissertation, Facultad de Filosofía y Letras, Universidad de Buenos Aires, Buenos Aires.

Vidal H, Winograd A.1986. El factor humano. Modificaciones antropogénicas en la paleoecología de otáridos en Tierra del Fuego. Anais da $2^{a}$ Reuniâo de trabalho de especialistas em mamíferos aquáticos da America do Sul. Río de Janeiro.

Whitaker AR, Hildebrandt WR. 2011. Why were northern fur seals spared in Northern California? A cultural and archaeological explanation. Human Impacts on Seals, Sea Lions, and Sea Otters. Integrating Archaeology and Ecology in the Northeast Pacific, Braje TJ, Rick T (eds). University of California Press Berkeley: Los Angeles and London; 197-219.

Zangrando AF. 2009a. Historia evolutiva y subsistencia de cazadores-recolectores marítimos de Tierra del Fuego. Colección Tesis de Doctorado, Sociedad Argentina de Antropología, Buenos Aires.
Zangrando AF. 2009b. Is fishing intensification a direct route to hunter-gatherer complexity? A case study from the Beagle Channel region (Tierra del Fuego, southern South America). World Archaeology 41(4): 589-608.

Zangrando AF, Orquera LA, Piana EL. 2010. Diversificación e intensificación de recursos animales en la secuencia arqueológica del canal Beagle (Tierra del Fuego, Argentina). Zooarqueología a principios del siglo XXI: aportes teóricos, metodológicos y casos de estudio Gutiérrez MA, De Nigris M, Fernández PM, Giardina M, Gil AF, Izeta A, Neme G, Yacobaccio HD (eds). Ediciones del Espinillo: Buenos Aires; 359-370.

Zangrando AF, Tessone A, Vázquez M. 2009. El uso de espacios marginales en el archipiélago fueguino: implicaciones de la evidencia arqueológica de Bahía Valentín. Arqueología de la Patagonia. Una mirada desde el último confín, Salemme M, Santiago F, Alvarez M, Piana E, Vázquez M, Mansur ME (eds). Editorial Utopias: Ushuaia; 47-62. 